\title{
Endophytic Fungi from Aegle marmelos Plant: A Potent and Innovative Platform for Enhanced Cellulolytic Enzyme Production
}

\author{
Pradeep Kumar Badiya ${ }^{\mathrm{a}}$, Sai Praneeth Thota ${ }^{\mathrm{a}}$, Sandeep Yerram ${ }^{\mathrm{a}}$, Praveen V. Vadlani, ${ }^{\mathrm{b}, \mathrm{c}}$, \\ Pallavi Vedantam ${ }^{\mathrm{d}}$, Sai Sathish Ramamurthy ${ }^{\mathrm{a},{ }^{*}}$, Nageswara Rao Golakoti ${ }^{\mathrm{a}}$, Robin Sharma ${ }^{\mathrm{e}}$ \\ and B.S. Vijaya Kumar
}

\author{
${ }^{a}$ Molecular Bioprocessing Laboratory, Department of Chemistry, Sri Sathya Sai Institute of Higher Learning, \\ Prasanthi Nilayam, A.P-515134, India \\ ${ }^{b}$ Bioprocessing and Renewable Energy Laboratory, Department of Grain Science and Industry, India \\ ${ }^{c}$ Department of Chemical Engineering, Kansas State University, Manhattan, KS 66506, USA \\ ${ }^{d}$ Memorial Sloan Kettering Cancer Center, 1275 York Avenue, New York, 10065, USA \\ ${ }^{e}$ Department of Biosciences, Sri Sathya Sai Institute of Higher Learning, Prasanthi Nilayam Campus, \\ Puttaparthi, Anantapur Dist., Andhra Pradesh, India
}

\begin{abstract}
Fungi have a prominent status in fermentation for the production of different bio-products. Endophytic fungi isolated from medicinal plants are particularly formidable in their adaptability to solid state fermentation as an extension of its natural habitat and are also a potent source of broad-spectrum cellulolytic enzymes. We report for the first time the use of endophytic fungus isolated from Aegle marmelos for enhanced cellulolytic enzymes production from groundnut shell (GNS) as substrate. ImageJ software identified Trichoderma harzianum as an endophytic fungus having maximum radial growth rate. A systematic comparison of the endophytic fungus with Aspergillus oryzae, under solid state fermentation (SSF) and submerged fermentation (SmF) conditions was performed and enhanced cellulase production was observed by the endophytic fungus $(4.27 \mathrm{FPU} / \mathrm{ml})$ under SSF environment compared to SmF (2.35 FPU/ml). A comprehensive understanding of the systemic breakdown in the structural integrity of the biomass has been achieved using a synergy of enzyme assay protocols, spectral and thermal based techniques. The use of endophytic fungi in SSF systems in our study lays the basis for the production of other industrially important enzymes. The present study opens the door for the synergistic use of endophytic and epiphytic fungi for the production of cellulolytic enzyme.
\end{abstract}

Keywords: Fermentation, Biomass, Fungi, Extraction, Agricultural Wastes.

\section{INTRODUCTION}

Fossil fuels are a non-renewable energy source used to make products such as chemicals, solvents, lastics, synthetic fabrics, and lubricants; the major end use being transportation fuels [1]. Natural gas and battery operated vehicles are alternatives to liquid fuels but not cost effective and the technology is at its early stage [1]. However, biofuels produced from renewable bio-sources such as lignocellulosic biomass (LCB) offer a cleaner, sustainable and affordable alternative [2, 3]. A study reported that ethanol from cellulosic biomasses reduces $85 \%$ of greenhouse gases emission over gasoline [4].

An extension to cellulosic ethanol from biomass has been the use of agricultural wastes for bioethanol production $[5,6]$. The agro crop residues being the most abundant source of carbon in nature have significantly helped to alleviate global warming and balance the growing global energy demands [6].

\footnotetext{
*Address correspondence to this author at the Department of Chemistry, Sri Sathya Sai Institute of Higher Learning, Prashanthi Nilayam, 515134, India; Tel: +918790314405; Fax: 08555286919; E-mail: rsaisathish@sssihl.edu.in
}

However, the main limiting factor in bioprocessing is the structural integrity of LCB which contributes to soaring costs of ethanol production [7]. Bioprocessing in this context plays a key role in lowering the cost of ethanol production with the use of enzymatic and fermentation methods [8]. Structural composition of LCB in particular plays a vital role in the choice of pretreatment of LCB [3, 9-11]. We have shown in an earlier investigation that lignin content and its binding pattern is a significant factor in cellulosic ethanol production from mutant brown midrib sorghum [12].

In continuation to our effort on low-cost ethanol production, we have explored in the current investigation an under-researched and unique class of fungal species for enhanced generation of cellulase enzymes. Several studies have reported different fungal species employed in the production of cellulase enzymes from LCB using solid state (SSF) and submerged (SmF) methods [3, 13-21]. However, a comparative study on the cellulolytic enzymes production from SSF and SmF by endophytic fungi with epiphytic fungi has not been reported so far. 
Endophytes are microorganisms (bacteria or fungi) that colonize living plant tissue intra-cellularly or intercellularly [22]. A variety of interactions exist between fungal endophytes and their host plants, ranging from symbiotic to antagonistic or mutualistic relationship [23]. They produce active pharmacological substances with biotechnological potential such as anti-fungal agents (quercine), anti-tumor agent (taxol) along with enzymes and toxins [24]. Many endophytic fungi isolated from medicinal plants have known to produce anti-microbials and unique bioactive compounds [25]. Importantly, the status of the interaction between an endophyte and host may be ephemeral and the fungi become saprophytic which suggests that they are capable of generating broad-spectrum ligno-cellulolytic enzymes system [26].

In this study, we have chosen endophytic fungi from Aegle marmelos, a well-known plant with medicinal significance. Many parts of this plant are used in Unani and Ayurveda medicine for the treatment of diverse ailments, including dysentery, diarrhea, and dyspeptic symptoms [25]. In this investigation, 23 endophytic fungi were isolated from $A$. marmelos and screened for their cellulolytic enzyme production capability [26-27]. Simultaneously the selected fungus was characterized and identified as T. harzianum by Agarkar Research Institute, Pune. Cellulolytic enzymes produced by $T$. harzianum were identified, the enzyme activity was measured, and the extent of degradation of groundnut shell (GNS) was presented. Thermal and spectroscopic techniques were used to assess the systemic changes in the structural recalcitrance of the pristine, pretreated and fungal treated biomass.

\section{MATERIALS AND METHODS}

\section{Fungal Screening Using Image J Software}

The endophytic fungi were screened for their ability to produce the cellulolytic enzymes. Agar medium enriched with $1 \% \mathrm{CMC}$ or $1 \%$ salicin was sterilized and poured into petri plates and subsequently sealed with parafilm. A weighed quantity of the fungal sample was taken from the test tube cultures and placed at the center of the petri dish containing the substrate enriched agar medium. The images of the fungal growth were captured everyday with the help of a digital camera. The photographs were then analyzed with the help of ImageJ 1.32j software (National Institute of Health, Bethesda, Maryland, USA) [3, 28]. The radial area of the fungal growth was expressed in $\mathrm{cm}^{2}$ and compared across the fungi. Since hydrolytic enzyme production is typically growth associated [3], the fungal specimen showing enhanced growth rate $\left(\mathrm{cm}^{2} /\right.$ day) was subsequently taken for SSF and SmF studies.

\section{Substrate Preparation}

The GNS was procured directly from the local agricultural mills (Anantapur, India). The substrate was soaked in water for an hour and filtered. This process was repeated several times to remove any undesirable impurities and suspended particles. The substrate was then air dried, without exposing to direct sunlight with sufficient care being taken while drying. The substrate was then rendered moisture free by heating in a hot air oven at $80{ }^{\circ} \mathrm{C}$ for $12 \mathrm{hrs}$. The dried samples were stored in plastic bag until used for further processing. The GNS was further subjected to alkali pretreatment to remove the soluble lignin as described by Brijwani et al., [29]. The material was soaked in $1 \% \mathrm{NaOH}(0.25 \mathrm{M})$ solution, heated in a boiling water bath for an hour and then cooled to room temperature [3, 29-30]. The alkali treated substrate was then separated from the solution by filtering through a muslin cloth and washed free of alkali. The modified substrate was then squeezed and dried overnight in an oven at $80{ }^{\circ} \mathrm{C}$ and stored till further study. The treated biomass was ground in an electrical grinder, sieved to obtain particle size $<1000$ microns and then used as a substrate in the SmF and SSF studies [29].

\section{Inoculum Preparation}

Endophytic microfungi were isolated from various parts of Aegle marmelos plant and individual colonies were obtained using Potato Dextrose Agar (PDA) as culture medium. The fungal cultures were maintained in PDA medium as slants at $30{ }^{\circ} \mathrm{C}$ for 7 days. The PDA slants were incubated under static conditions until a mycelia mat was formed. Ten milliliters of Mandel and Reese medium (MRM) was added and vortexed to obtain fungal spores in a suspension form. The final concentration was set to $10^{7}$ spores $/ \mathrm{mL}$.

\section{Fermentation Protocol}

The batch SSF system was designed with modifications from Brijwani and Vadlani method [9]. A $250 \mathrm{ml}$ conical flask containing $2 \mathrm{~g}$ of GNS was taken and $5 \mathrm{ml}$ of Mandel Resse Medium (MRM) and $5 \mathrm{ml}$ of deionized water were added to this flask to ensure $70 \%$ moisture content in the fermentation system. The flasks were sterilized at $121{ }^{\circ} \mathrm{C}$ for $30 \mathrm{~min}$ at $15 \mathrm{PSI}$ before inoculation with the fungal suspension $\left(10^{7}\right.$ spores $\left./ \mathrm{ml}\right)$. 
The flasks were then incubated at $30{ }^{\circ} \mathrm{C}$ temperature and removed from the incubator for enzyme extraction on a 2 day interval period spanning a total of 10 days [3]. In the current study, we have presented data for the $6^{\text {th }}$ and $10^{\text {th }}$ days as the enzyme production was enhanced on these days. In the case of SmF system, 5 $\mathrm{ml}$ of MRM and $15 \mathrm{ml}$ deionized water were added to the flask to submerge the contents completely. The rest of the procedure was similar to the SSF system.

\section{Enzyme Activity Determination}

In case of the SSF system, after incubation, $30 \mathrm{ml}$ of $0.05 \mathrm{M}$ citrate buffer $(\mathrm{pH} 4.8)$ was added to each flask and left for shaking at $100 \mathrm{rpm}$ for $30 \mathrm{~min}$ at $4{ }^{\circ} \mathrm{C}$ to recover the extracellularly secreted enzymes. The extract was filtered using muslin cloth to separate the suspended spores along with the biomass. From the supernatant, $0.5 \mathrm{ml}$ was used for determination of the enzyme activity by performing different enzyme assays (Filter Paper unit assay, Carboxymethylcellulase assay and Salicin assay). For SmF systems, the enzymes were extracted with $10 \mathrm{ml}$ of $0.05 \mathrm{M}$ citrate buffer $(\mathrm{pH}$ 4.8) and rest of the procedure was maintained the same as in the SSF system. The study has been carried out in triplicates.

\section{Biomass Characterization}

The enzyme extract was filtered; the residual biomass and fungal debris were washed thoroughly with deionized water and sterilized by autoclaving for 30 mins. The fungal treated biomass was then dried in an oven for $24 \mathrm{hrs}$ at $80^{\circ} \mathrm{C}$ and subsequently utilized for DTG, DSC and FT-IR spectroscopic analysis.

\section{DSC-DTG Analysis of Biomass Samples}

The untreated, alkali pretreated and fungal treated biomass samples were dried and studied using DTG and DSC techniques to obtain information on the rigidity of the biomass. Five to ten $\mathrm{mg}$ of the sample was loaded in an alumina crucible. The TGA-DSC instrument (METTLER TOLEDO TGA/DSC1) was operated at a heating range of $30-1000{ }^{\circ} \mathrm{C}$ with a uniform increment of $0.5{ }^{\circ} \mathrm{C}$ per sec. Percentage weight loss (in $\mathrm{mg}$ ) of the loaded sample was analyzed by TGA and the heat flow (in $\mathrm{mW}$ ) was analyzed using the DSC platform.

\section{FT-IR Analysis of Biomass Samples}

The samples were dried in an oven at $80{ }^{\circ} \mathrm{C}$ for $2 \mathrm{~h}$ and then studied using the FT-IR technique. $2 \mathrm{mg}$ of the biomass was accurately weighed in an electronic balance and ground with dry $\mathrm{KBr}(75 \mathrm{mg})$ and pelletized. The spectrum of the pellet was then recorded using the FT-IR spectrometer (THERMO SCIENTIFIC, NICOLET iS10). The spectra of the samples including the control and blank were compared to understand the changes in the functional group pattern that is reflected in the structural modification in the pretreated and the fungal treated biomass.

\section{RESULTS AND DISCUSSION}

\section{Selection of Endophytic Fungus for Enhanced Enzyme Production}

To evaluate the use of endophytic fungi for cellulolytic enzymes production, 23 endophytic fungi isolated from the Aegle marmelos plant were screened in comparison with $A$. oryzae (NCIM1212) obtained from National Collection of Industrial Microorganisms (NCIM, Pune, India). We have earlier worked with $A$. oryzae for cellulolytic enzyme production $[9,29]$, hence we considered as reference fungus. In the current study we have introduced the use of Image $\mathrm{J}$ software as a chemical free and rapid screening technique.

The images of the fungal growth on the petri plates for the $1^{\text {st }}, 2^{\text {nd }}$ and $3^{\text {rd }}$ day after incubation are shown in Figures $1 \mathrm{a}-1 \mathrm{c}$. The radial growth area of the fungi on the CMC or the salicin enriched agar media was measured using the Image $\mathrm{J}$ software. The results are tabulated and compared across the fungi in Table 1. The fungal species with the assigned code -B8L, showed an enhanced area of growth on the $3^{\text {rd }}$ day compared to other endophytic fungi and hence was selected for further study. The images of $A$. oryzae $\left(12.57 \mathrm{~cm}^{2}\right)$ and B8L $\left(51.75 \mathrm{~cm}^{2}\right)$ growth in CMC enriched agar medium have been depicted in Figures 1d \& 1e. The growth of $A$. oryzae $\left(9.80 \mathrm{~cm}^{2}\right)$ and $\mathrm{B} 8 \mathrm{~L}$ $\left(57.27 \mathrm{~cm}^{2}\right)$ on salicin enriched agar on the $3^{\text {rd }}$ day of incubation are shown in Figures $\mathbf{1 f} \& \mathbf{1 g}$.

\section{Identification of the Fungus}

Fungal endophytes have been known to spread across different plant species and thereby decrease the phylogenetic distance between the host species. On the other hand, phylogenetic diversity of many fungal endophytic assemblages has been explored to understand the association patterns with particular host plant species [3, 31]. Our investigation confirms the presence of the prevalent endophyte $T$. harzianum that was isolated, sequenced, amplified and identified from the phylogenetic tree. 


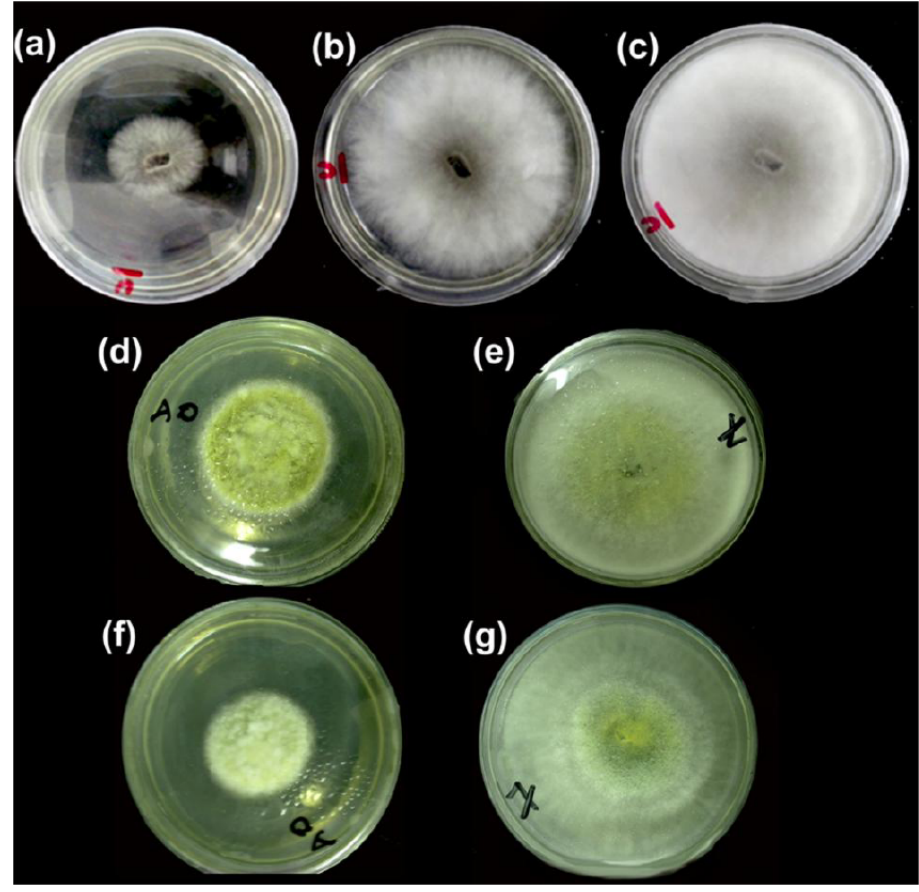

Figure 1: Images of the radial growth of the fungi on the petri plates on $1^{\text {st }}(\mathbf{a}), 2^{\text {nd }}(\mathbf{b})$ and $3^{\text {rd }}(\mathbf{c})$ day after incubation. $A$. oryzae (d) and T. harzianum (e) growth on CMC enriched agar medium. A. oryzae (f) T. harzianum (g) growth on salicin enriched agar medium.

Table 1: Monitoring of the Radial Growth Area of the Fungi Grown on the CMC-PDA and Salicin-PDA Media for Three Days with Image J Software

\begin{tabular}{|c|c|c|c|c|c|c|c|}
\hline \multirow[t]{2}{*}{ Name of the fungi } & \multirow[t]{2}{*}{ Code } & \multicolumn{3}{|c|}{$\begin{array}{l}\text { Area of growth in CMC-PDA medium } \\
\qquad\left(\mathrm{cm}^{2} / \mathrm{day}\right)\end{array}$} & \multicolumn{3}{|c|}{$\begin{array}{l}\text { Area of growth in Salicin-PDA } \\
\text { medium ( } \mathrm{cm}^{2} / \text { day) }\end{array}$} \\
\hline & & Day 1 & Day 2 & Day 3 & Day 1 & Day 2 & Day 3 \\
\hline Trichoderma harzianum & B8L & 3.32 & 27.44 & 51.75 & 2.8 & 25.98 & 57.27 \\
\hline Unidentified & B5J & 2.54 & 11.45 & 22.42 & 0.74 & 2.35 & 10.91 \\
\hline Unidentified & B7G & 13.41 & 47.74 & 60.5 & 8.46 & 48.55 & 57.88 \\
\hline Fusarium species & L1D & 0.4 & 2.45 & 5.35 & 0.41 & 2.21 & 2.71 \\
\hline Hyalopus species & L5L' & 0.47 & 3.01 & 5.02 & 0.44 & 1.93 & 3.18 \\
\hline Unidentified & L5K & 0.24 & 0.34 & 1.33 & 0.26 & 0.26 & 1.43 \\
\hline Fusarium monoliforma & L10E & 0.29 & 0.46 & 1.54 & 0.22 & 0.59 & 0.82 \\
\hline Phoma chrysanthemicola & L10l & 1.97 & 7.24 & 15.6 & 0.57 & 5.71 & 12.67 \\
\hline Hullecells & S1J & 0.23 & 0.24 & 2.36 & 0.26 & 0.45 & 0.86 \\
\hline Unidentified & $\mathrm{S} 8 \mathrm{H}$ & 0.52 & 1.21 & 2.18 & 1.22 & 3.42 & 6.18 \\
\hline Unidentified & S1D & 0.79 & 3.01 & 5.29 & 1.47 & 2.84 & 3.49 \\
\hline Unidentified & S1E & 1.26 & 8.42 & 18.18 & 0.44 & 1.41 & 2.14 \\
\hline Unidentified & S8I & 1.34 & 5.94 & 10.11 & 0.31 & 2.58 & 6.79 \\
\hline Vegetative mycelium & S16L & 1.29 & 4.23 & 26.88 & 1.64 & 4.68 & 14.02 \\
\hline
\end{tabular}


(Table 1). Continued.

\begin{tabular}{|c|c|c|c|c|c|c|c|}
\hline \multirow[t]{2}{*}{ Name of the fungi } & \multirow[t]{2}{*}{ Code } & \multicolumn{3}{|c|}{$\begin{array}{l}\text { Area of growth in CMC-PDA medium } \\
\qquad\left(\mathrm{cm}^{2} / \text { day }\right)\end{array}$} & \multicolumn{3}{|c|}{$\begin{array}{c}\text { Area of growth in Salicin-PDA } \\
\left.\text { medium ( } \mathrm{cm}^{2} / \text { day }\right)\end{array}$} \\
\hline & & Day 1 & Day 2 & Day 3 & Day 1 & Day 2 & Day 3 \\
\hline Unidentified & L2B' & 0.71 & 2.1 & 2.98 & 0.32 & 1.6 & 3.04 \\
\hline Unidentified & S4A & 0.29 & 4.83 & 10.68 & 4.39 & 47.06 & 52.98 \\
\hline
\end{tabular}

Based on phylogenetic analysis of PCR amplicons, the contig sequences of B8L was $100 \%$ identical to $T$. harzianum (Figure 2a). The representative sequence based on multiple sequence alignments indicated the presence of $T$. harzianum isolate, consisting of internal transcribed spacer $1,5.8 \mathrm{~S}$ ribosomal RNA gene, and internal transcribed spacer 2, complete sequence; and $28 \mathrm{~S}$ ribosomal RNA gene (Figure 2b). The BLAST alignment results have shown linear DNA nucleotide sequence of 619 bp (GenBank: KJ028794.1). The same strain has been extensively studied and recently reported [32]. The phylogenetic tree has been depicted in Figure 2c. The results clearly indicate the presence of a potential endophytic species with promising chemical and enzymatic capabilities.

\section{Quantification of Enzyme Activity}

The extracellular enzymes released by $T$. harzianum and $A$. oryzae fungal species were extracted on the $6^{\text {th }}$ and $10^{\text {th }}$ day from the date of incubation, with citrate buffer $(\mathrm{pH} 4.8)$ and stored in a refrigerator at $4{ }^{\circ} \mathrm{C}$. The enzyme extract was then quantified for different cellulolytic enzymes: cellulase, endo- $\beta-1,4$-glucanase and $\beta$-glucosidase by performing the standard filter paper assay (FPA), CMC assay and Salicin assay [3, 33].

\section{Estimation of Cellulase Enzyme}

The FPA based cellulase activity of the fungi on the $6^{\text {th }}$ and $10^{\text {th }}$ days of incubation in both the SSF and $\mathrm{SmF}$ conditions have been presented in Figure 3a. The cellulase activity was higher in the SSF environment, compared to SmF. The highest enzyme activity was observed in the case of $T$. harzianum (4.27 FPU/mL) studied under the SSF condition on the $10^{\text {th }}$ day that is significantly more than that of $A$. oryzae (2.71 $\mathrm{FPU} / \mathrm{mL})$.

\section{Estimation of Endo- $\beta-1,4,-$ Glucanase}

The endo- $\beta$-glucanase activity observed on the $6^{\text {th }}$ and $10^{\text {th }}$ day has been presented in Figure $\mathbf{3 b}$.

Maximum enzyme activity was observed on the $6^{\text {th }}$ day under the SSF conditions with $A$. oryzae $(20.00 \mathrm{IU} / \mathrm{mL})$ followed by $T$. harzianum $(18.38 \mathrm{IU} / \mathrm{mL})$. In this case, the enzyme activity of the endophytic fungus was found to be comparable with that of the epiphytic fungus.

(a)
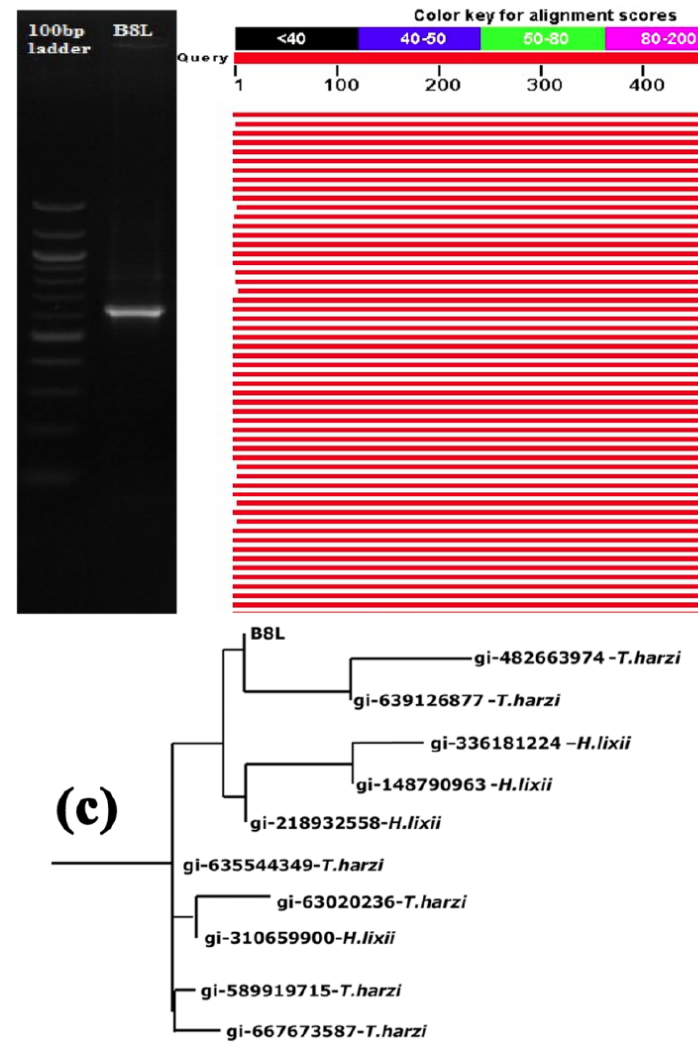

Figure 2: Fingal identification details. (a) Amplicon photograph electrophoresed in a $1 \%$ agarose gel and visualized under UV, (b) Blast alignment bioinformatic tool BLAST of NCBI and (c) Phylogram.

\section{Estimation of $\beta$-Glucosidase}

In this study, on both the $6^{\text {th }}$ and $10^{\text {th }}$ days, the enzyme production was enhanced under SSF condition with $A$. oryzae showing an activity of $15.38 \mathrm{IU} / \mathrm{ml}$ and $T$. harzianum with $17.00 \mathrm{IU} / \mathrm{mL}$ (Figure 3c). Typically, $T$. harzianum is known to produce less $\beta$-glucosidase 

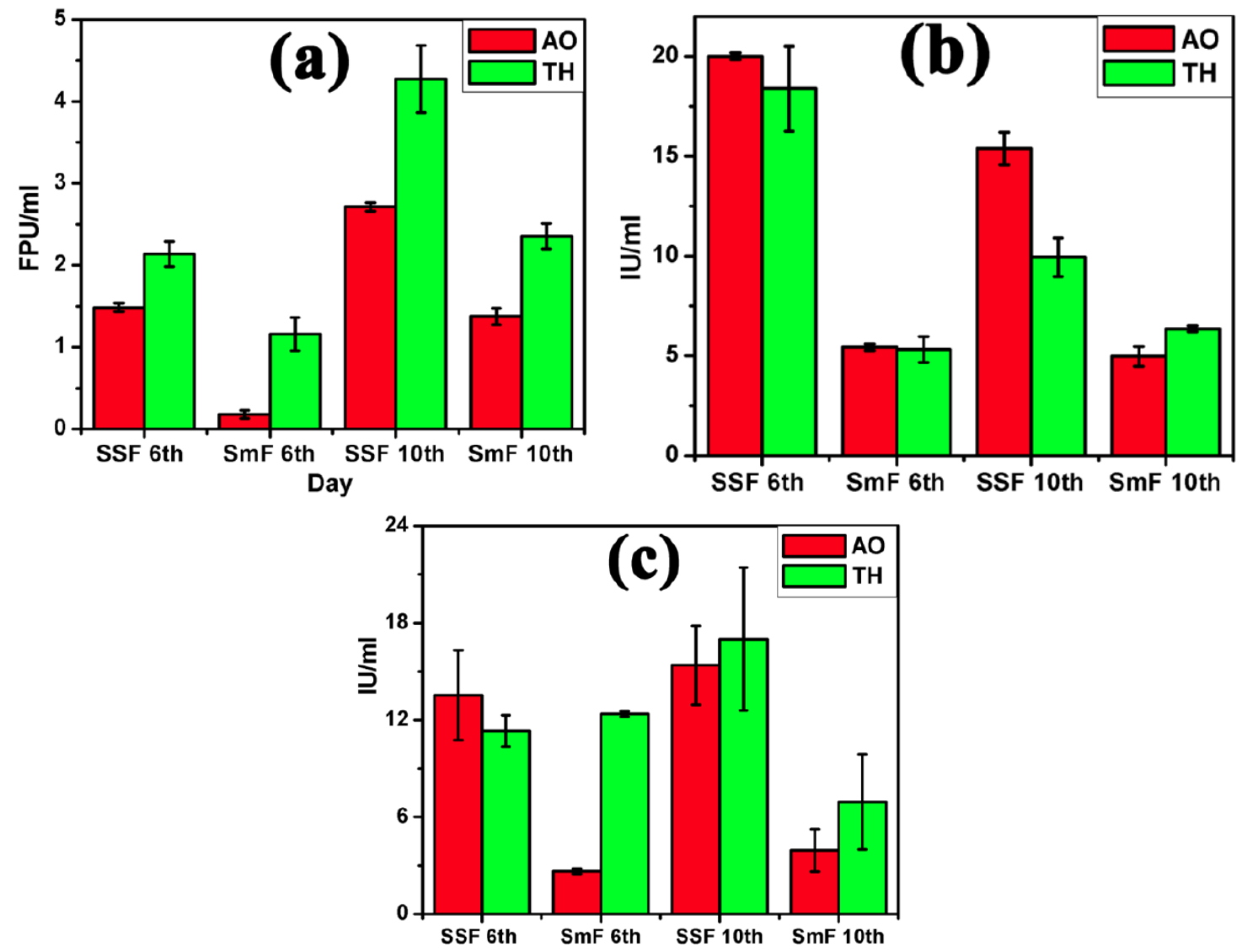

Figure 3: Quantification of enzyme activity (a) cellulase, (b) Endo- $\beta-1,4-$ glucanase and (c) $\beta$-glucosidase. (AO- $A$. oryzae, THT. harzianum).

activity [12]; however, the endophytic fungus of the same Trichoderma spp. exhibited comparable $\beta$ glucosidase activity in our study. This indicates that the generation of the appropriate cellulolytic cocktail is indeed possible with the endophytic fungi. Further, better production of $\beta$-glucosidase by $T$. harzianum under the $\mathrm{SmF}$ condition, on both the $6^{\text {th }}$ day $(12.37$ $\mathrm{IU} / \mathrm{mL})$ and the $10^{\text {th }}$ day $(6.94 \mathrm{IU} / \mathrm{mL})$ was observed. This unusual behavior of $T$. harzianum can be explained as its adaptability to both the SSF and SmF environments, thereby having a pronounced enzyme production in both the cases.

Cellulase, endo- $\beta$-1,4-glucanase and $\beta$-glucosidase activities obtained from earlier literature are in the range of 0.55-1.74 FPU/mL, 3.12-33.80 IU/ml and 0.09$8.22 \mathrm{IU} / \mathrm{mL}$ respectively (Table $\mathrm{S1}$ ) [34-38]. When the enzyme activities obtained from current study cellulase (4.27 FPU $/ \mathrm{mL}$ - T. harzianum, $2.71 \mathrm{FPU} / \mathrm{mL}-A$. oryzae), endo- $\beta$-glucanase $(18.38 \mathrm{IU} / \mathrm{mL}-T$. harzianum \& $20.00 \mathrm{IU} / \mathrm{mL}-A$. oryzae) and $\beta$ glucosidase $(17.00 \mathrm{IU} / \mathrm{mL}$ - $T$. harzianum \& 15.38 $\mathrm{FPU} / \mathrm{mL}-A$. oryzae) were compared with the earlier reports in literature, it was observed that the amount of enzymes released by these endophytic fungi was enhanced. Overall the enzyme production was found to be more in SSF environment than in SmF conditions. This is in concurrence with our hypothesis that the endophytic fungi closely mimic their natural habitat when used in SSF conditions. As a result, the activity of enzymes was high compared to SmF.

\section{Biomass Characterization}

\section{Microscopic Characterization of Biomass}

The GNS biomass samples were analyzed using scanning electron microscopy (SEM). The untreated GNS (Figure 4a) was covered with lignin globules and presented a rough surface that was absent in the alkali treated GNS (Figure 4b). This indicated the soluble lignin removal on account of the alkali pretreatment and led to improved surface area and better fungal accessibility to the cellulose $[3,6]$. The SEM images of $A$. oryzae and $T$. harzianum fungal treated GNS under both the SmF and SSF conditions have been depicted in Figures $\mathbf{4 c - 4 f}$. These SEM images provide a qualitative validation of the changes in the structural morphology of the GNS due to pretreatment and fungal treatment steps. 


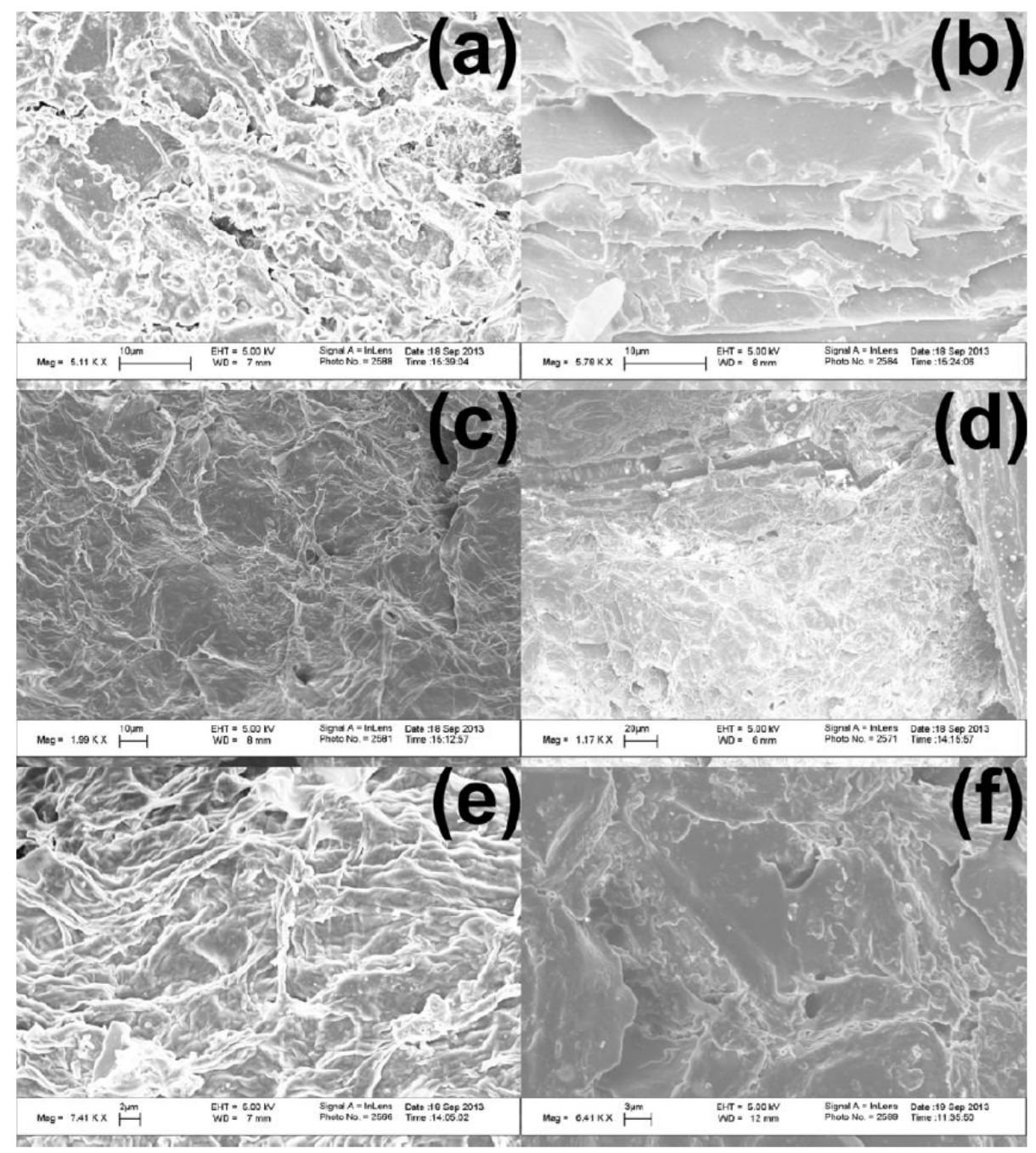

Figure 4: SEM photographs of (a) untreated GNS, (b) alkali treated GNS, A. oryzae treated GNS in (c) SmF and (d) SSF conditions and $T$. harzianum treated GNS in (e) SmF and (f) SSF conditions.

\section{Fourier Transformed Infrared (FT-IR) Spectroscopic Analysis}

FT-IR spectra of the fungal treated GNS were analyzed in comparison with the characteristic peaks of the individual biomass components (cellulose, hemicellulose and lignin). Different peaks from the FTIR spectra were identified and the intensities of $\%$ Transmittance and peak area were recorded and compared among the biomass samples. The FT-IR spectra of the fungal treated GNS in SSF and SmF conditions have been shown in Figures $5 a-5 c$ and Figures S1a-S1c.

The characteristic peak of the lignin aromatic carbonyl group (C-O) was seen at $1592 \mathrm{~cm}^{-1}$, while polysaccharide (hemicellulose and cellulose) and glycosidic linkage were seen at $1111 \mathrm{~cm}^{-1}$ and 1073 $\mathrm{cm}^{-1}$ respectively, (Table $\mathbf{S 2}$ ). All the peaks were compared across the spectra of the fungal treated GNS under the SSF and SmF conditions using the protocol described elsewhere $[3,12]$.

The reduced \% Transmittance and the area were noticed at 1592, 1111, and $1073 \mathrm{~cm}^{-1}$ in the fungal fortified biomass in SSF conditions because of the decreased substrate opacity when compared to SmF. This confirms better saccharification of the substrate in SSF environment in coherence with the earlier conclusions drawn from the SEM analysis.

\section{Thermal Analysis of the Biomass}

After the enzymes were extracted from the fermentation flask, the fungal treated substrate was dried, sterilized and subjected to thermal analysis. Nonisothermal differential scanning calorimetric analysis of the substrate was performed. From the DSC thermogram, it was observed that the cellulose and hemicellulose decomposed in the temperature range of 

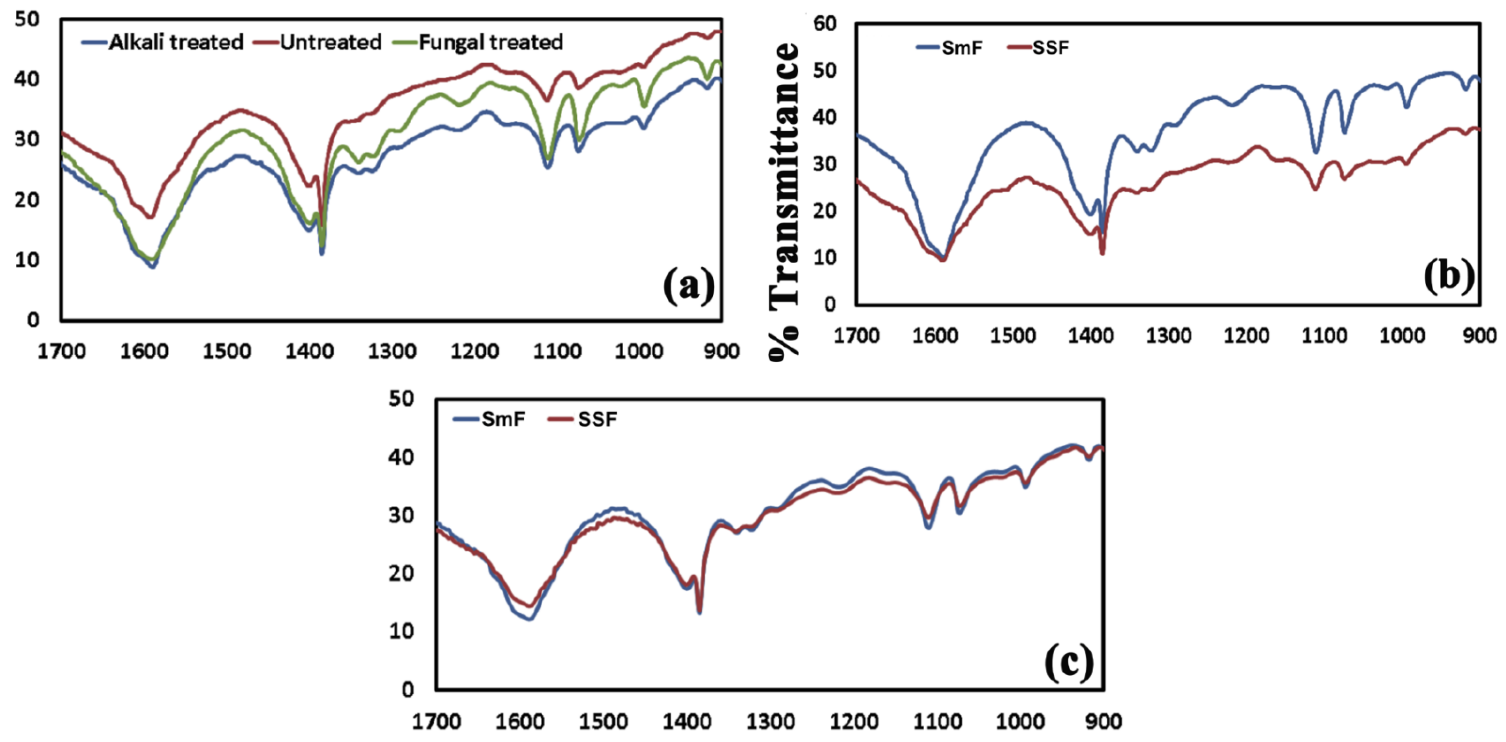

Wavenumber $\left(\mathrm{cm}^{-1}\right)$

Figure 5: FT-IR spectra of the fungal treated GNS on the $6^{\text {th }}$ day. (a) Comparison of the untreated, alkali treated and fungal treated GNS. Comparison of SSF vs. SmF: (b) A. oryzae treated GNS and (c) T. harzianum treated GNS.
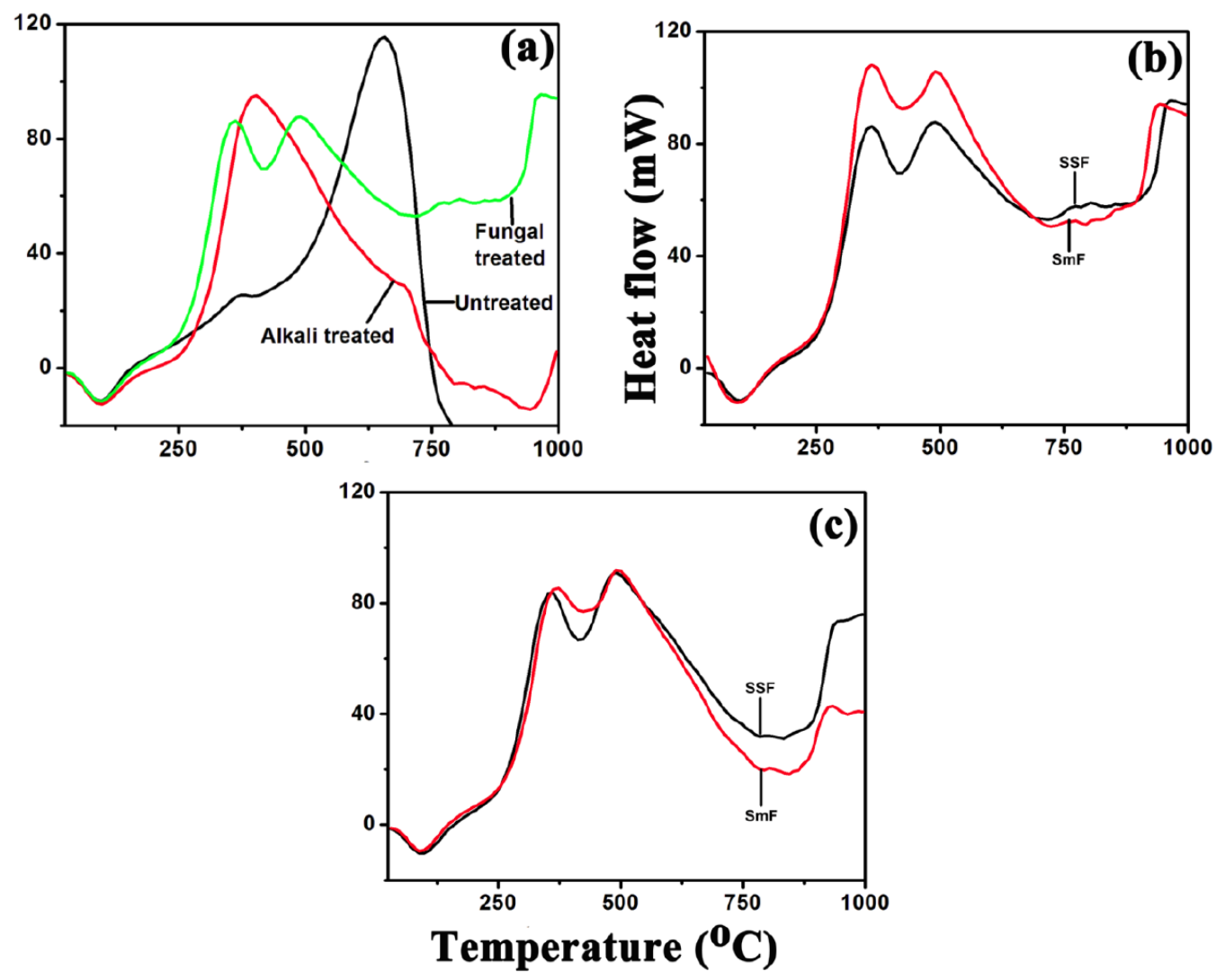

Figure 6: DSC thermograms of the fungal treated GNS in the SSF and SmF environments on the $6^{\text {th }}$ day. (a) Comparison of the untreated, alkali treated and fungal treated GNS (b) A. oryzae treated GNS and (c) T. harzianum treated GNS.

200-380 ${ }^{\circ} \mathrm{C}$ and $250-380{ }^{\circ} \mathrm{C}$, whereas decomposition of the lignin ranged from $180-900{ }^{\circ} \mathrm{C}[3,39]$. From the exothermic profile, due to the combustion of the biomass, two distinct regions of combustion were identified in the thermogram of DSC (Figure 6 and Figure S2). The first region of combustion was identified as a low volatile zone and the second region as the combustion of the high volatile components like 
Table 2: DSC Analysis of the Fungal Treated GNSS

\begin{tabular}{|c|c|c|c|c|c|c|c|c|c|}
\hline \multirow{3}{*}{\multicolumn{2}{|c|}{ Sample ID }} & \multicolumn{4}{|c|}{ A. oryzae } & \multicolumn{4}{|c|}{ T. harzianum } \\
\hline & & \multicolumn{2}{|c|}{ SSF } & \multicolumn{2}{|c|}{ SmF } & \multicolumn{2}{|c|}{ SSF } & \multicolumn{2}{|c|}{ SmF } \\
\hline & & Day6 & Day10 & Day6 & Day10 & Day6 & Day10 & Day6 & Day10 \\
\hline \multirow{2}{*}{$\begin{array}{l}\text { Maximum heat } \\
\text { flow (mW) }\end{array}$} & $\begin{array}{c}\text { Light } \\
\text { volatiles }\end{array}$ & 86.36 & 92.60 & 103.30 & 109.29 & 83.83 & 106.19 & 85.42 & 4.50 \\
\hline & $\begin{array}{c}\text { Heavy } \\
\text { volatiles }\end{array}$ & 87.80 & 98.07 & 108.52 & 97.36 & 91.05 & 95.99 & 92.00 & 38.12 \\
\hline \multirow{2}{*}{ Temperature $\left({ }^{\circ} \mathrm{C}\right)$} & $\begin{array}{c}\text { Light } \\
\text { volatiles }\end{array}$ & $214-411$ & $245-401$ & $214-423$ & $245-433$ & $245-421$ & $245-423$ & $245-431$ & $296-448$ \\
\hline & $\begin{array}{c}\text { Heavy } \\
\text { volatiles }\end{array}$ & $411-697$ & $401-726$ & $423-726$ & $433-716$ & $421-785$ & $423-716$ & $431-794$ & $448-804$ \\
\hline
\end{tabular}

fixed carbon. These two regions were identified and analyzed in all of the thermograms of the fungal treated GNS (Table 2).

A comparative observation of the exothermic peaks and the heat flow values in the DSC thermograms of the pretreated and fungal treated biomass under SSF and $\mathrm{SmF}$ conditions were indicative of the following:

i. Softening of the fungal treated GNS indicated by the shift of the exothermic peaks to lower temperatures and reduced heat flow values.

ii. The fungal treated GNS had distinct peaks corresponding to cellulose and hemicellulose in consonance with the breakdown of the biomass on fungal growth.

iii. The combustion temperature range of low volatiles was lower in the case of SSF than in SmF conditions, indicative of a better softening of the biomass in the SSF environment.

DTG analysis of the fungal treated substrate was carried out to analyze the different pyrolytic regions of the biomass decomposition. First derivative thermogravimetry was also used in our analysis. It was observed that during the first stage, for temperatures below $200{ }^{\circ} \mathrm{C}$ that corresponds to the drying period, mainly light volatiles like water were liberated throughout the system runtime $\left(5{ }^{\circ} \mathrm{C} / \mathrm{min}\right)$. Devolatilization was the major step in all of the thermochemical conversion processes involving the biomass (Figure 7 and Figure S3) [3]. This step has been represented by the second stage of decomposition, occurring at temperatures between 200 ${ }^{\circ} \mathrm{C}$ to $500{ }^{\circ} \mathrm{C}$, where the remarkable slope of the DTG curves have been observed. At this stage, it was observed that the weight of the tested materials was reduced to below $50 \%$. This is primarily due to the fact that $80 \%$ weight of the biomass is formed by the volatile fraction, and only around $20 \%$ of the weight is in the form of solid carbonaceous residue. Various temperature points were identified and tabulated for better comparison among the fungal treated substrates as shown in Table 3. 'Ti' has been designated as the initial temperature at which there was a first sign of weight loss in the sample. 'Tsp' is the starting point temperature at which the first inverse curve on the DTG line appears. 'Tep' is the end point temperature in the DTG curve, and Tmax the temperature where the maximum reaction occurs or maximum weight loss has been observed. All the points in the DTG curves were analyzed for all the samples under both the SSF and SmF conditions.

On comparison of all the tabulated data from the DTG analysis of the fungal treated GNS, it was observed that the maximum decomposition of the biomass was in the temperature range of $300-500{ }^{\circ} \mathrm{C}$. Tmax of the fungal treated GNS from the SSF system was observed to be at a lower temperature compared to the biomass from the SmF systems in agreement with the earlier results. A lower Tmax indicates greater softening of the biomass as a result of better saccharification. From the TGA/DTG thermogram of the $T$. harzianum treated substrate, Tmax observed on the $6^{\text {th }}$ and $10^{\text {th }}$ day of incubation in the SSF conditions were $309{ }^{\circ} \mathrm{C}$ and $321{ }^{\circ} \mathrm{C}$, respectively. This was observed to be lower than $320{ }^{\circ} \mathrm{C}$ and $347{ }^{\circ} \mathrm{C}$ as on the $6^{\text {th }}$ and $10^{\text {th }}$, respectively, in the SmF condition. This clearly indicated that the biomass softening was more pronounced in the SSF systems.

This also correlated well with the SEM and FT-IR analyses and enzyme activity data obtained from the fungal growth under SSF and SmF conditions. All of these results clearly indicate better access to the substrate for the fungi under the SSF environment and 

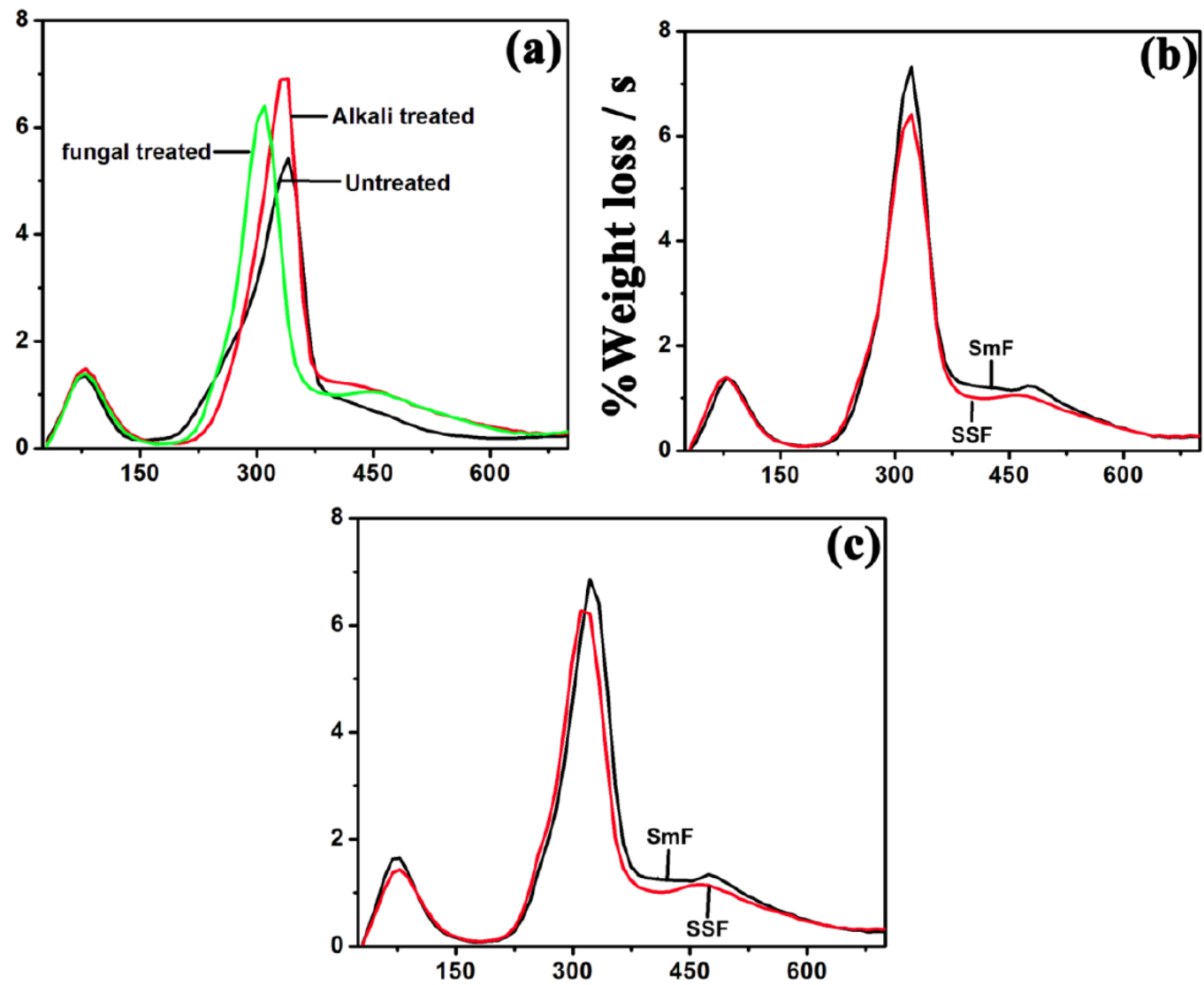

Temperature $\left({ }^{\circ} \mathrm{C}\right)$

Figure 7: DTG thermograms of the fungal treated GNS in SSF and SmF environments on the $6^{\text {th }}$ day. (a) Comparison of the untreated, alkali treated and fungal treated GNS, (b) $A$. oryzae treated GNS and (c) $T$. harzianum treated GNS.

Table 3: DTG Analysis of the Fungal Treated GNSS

\begin{tabular}{|c|c|c|c|c|c|c|c|c|}
\hline \multirow{3}{*}{ Sample ID } & \multicolumn{4}{|c|}{ A. oryzae } & \multicolumn{4}{|c|}{ T. harzianum } \\
\hline & \multicolumn{2}{|c|}{ SSF } & \multicolumn{2}{|c|}{ SmF } & \multicolumn{2}{|c|}{ SSF } & \multicolumn{2}{|c|}{ SmF } \\
\hline & Day6 & Day10 & Day6 & Day10 & Day6 & Day10 & Day6 & Day10 \\
\hline $\mathrm{Ti}\left({ }^{\circ} \mathrm{C}\right)$ & 79.28 & 79.48 & 78.96 & 88.52 & 79.44 & 79.20 & 79.55 & 78.72 \\
\hline $\operatorname{Tsp}\left({ }^{\circ} \mathrm{C}\right)$ & 183.03 & 183.06 & 183.17 & 193.19 & 183.11 & 183.30 & 183.31 & 182.44 \\
\hline $\operatorname{Tep}\left({ }^{\circ} \mathrm{C}\right)$ & 677.65 & 677.80 & 667.87 & 658.20 & 657.90 & 667.80 & 677.11 & 628.80 \\
\hline $\operatorname{Tmax} 2\left({ }^{\circ} \mathrm{C}\right)$ & 462.00 & 452.53 & 473.09 & $\begin{array}{l}413.00 \\
472.00\end{array}$ & 472.30 & 472.82 & 472.00 & - \\
\hline
\end{tabular}

the characterization studies suggested saccharification by the endophytic fungi in SSF conditions was better than in SmF.

\section{CONCLUSIONS}

In summary, the present study opens the door for the synergistic use of endophytic and epiphytic fungi for cellulolytic enzyme production. Particularly, the efficacy of using endophytic fungi in SSF systems was proved in our study and lays the framework for the production of other industrially important enzymes. Future studies should consider binary and ternary co-cultures of these fungi, along with fungi derived from other promising plant sources, for high-throughput cellulolytic enzyme production systems. A comprehensive understanding of the systemic breakdown in the structural integrity of 
the biomass has been achieved using a synergy of enzyme assay protocols, spectral and thermal based techniques.

\section{CONFLICT OF INTEREST}

The authors declare that they have no conflict of interests.

\section{ACKNOWLEDGEMENTS}

This work was made possible by funding from: DBTRamalingaswami Fellowship (Sanction Order No. 102/IFD/SAN/776/2015-16 dated: 28-05-2015) and DST-Fast Track, Govt. of India. The authors are grateful to Dr. M. M. Shaizumon, Indian Institute of Science Education and Research (IISER), Thiruvananthapuram, Kerala in obtaining the SEM images and the Dept. of Physics, SSSIHL, for access to the DSC and DTG instrumentation facilities. Author PVV is grateful to the Gary and Betty Lortscher Endowment and Kansas State University for his sabbatical at SSSIHL. The authors are grateful to the founder chancellor, SSSIHL, Bhagawan Sri Sathya Sai Baba for his endless motivation and providing facilities to pursue research.

\section{SUPPLEMENTAL INFORMATION}

The supplemental information can be downloaded from the journal website along with the article.

\section{REFERENCES}

[1] Frumkin $\mathrm{H}$, Hess J, Vindigni S. Energy and public health: the challenge of peak petroleum. Public Health Rep 2009; 124(1): 5-19. https://doi.org/10.1177/003335490912400103

[2] Wyman CE. Ethanol from lignocellulosic biomass: technology, economics, and opportunities. Bioresour Technol 1994; 50(1): 3-15. https://doi.org/10.1016/0960-8524(94)90214-3

[3] Thota SP, Badiya PK, Yerram S, Vadlani PV, Pandey M, Golakoti NR, Belliraj SK, Dandamudi RB, Ramamurthy SS. Macro-micro fungal cultures synergy for innovative cellulase enzymes production and biomass structural analyses. Renewable Energy 2017; 103: 766-73. https://doi.org/10.1016/j.renene.2016.11.010

Wang M. Updated energy and greenhouse gas emission results of fuel ethanol. In the 15th International Symposium on Alcohol Fuels, San Diego 2005; pp. 26-28.

[5] Agrawal R, Satlewal A, Gaur R, Mathur A, Kumar R, Gupta RP, Tuli DK. Pilot scale pretreatment of wheat straw and comparative evaluation of commercial enzyme preparations for biomass saccharification and fermentation. Biochemi Eng J 2015; 102: 54-61. https://doi.org/10.1016/j.bej.2015.02.018

[6] Walker K, Vadlani P, Madl R, Ugorowski P, Hohn KL. Ethanol fermentation from food processing waste. Environ Prog Sustainable Energy 2013; 32(4): 1280-3. https://doi.org/10.1002/ep.11700
[7] Fernandes DL, Pereira SR, Serafim LS, Evtuguin DV, Xavier AM. Second generation bioethanol from lignocellulosics: processing of hardwood sulphite spent liquor. In Bioethanol 2012; InTech

[8] Bak JS, Ko JK, Han YH, Lee BC, Choi IG, Kim KH. Improved enzymatic hydrolysis yield of rice straw using electron beam irradiation pretreatment. Bioresour Technol 2009; 100(3): 1285-90.

https://doi.org/10.1016/j.biortech.2008.09.010

[9] Brijwani K, Vadlani PV. Cellulolytic enzymes production via solid-state fermentation: effect of pretreatment methods on physicochemical characteristics of substrate. Enzyme Res $2011 ; 2011$.

[10] Ghorbani F, Karimi M, Biria D, Kariminia HR, Jeihanipour A Enhancement of fungal delignification of rice straw by Trichoderma viride $\mathrm{sp}$. to improve its saccharification. Biochem Eng J 2015; 101: 77-84. https://doi.org/10.1016/j.bej.2015.05.005

[11] Akhtar N, Gupta K, Goyal D, Goyal A. Recent advances in pretreatment technologies for efficient hydrolysis of lignocellulosic biomass. Environ Prog Sustainable Energy 2016; 35(2): 489-511. https://doi.org/10.1002/ep.12257

[12] Guragain YN, Ganesh KM, Bansal S, Sathish RS, Rao N Vadlani PV. Low-lignin mutant biomass resources: effect of compositional changes on ethanol yield. Ind Crops Prod 2014: 61: 1-8

https://doi.org/10.1016/j.indcrop.2014.06.014

[13] Bauermeister A, Amador IR, Pretti CP, Giese EC, Oliveira AL, Alves da Cunha MA, Rezende MI, Dekker RF, Barbosa AM. $\beta-(1 \rightarrow 3)$-Glucanolytic Yeasts from Brazilian Grape Microbiota: Production and Characterization of $\beta$ Glucanolytic Enzymes by Aureobasidium pullulans 1WA1 Cultivated on Fungal Mycelium. J Agric Food Chem 2015; 63(1): 269-278 https://doi.org/10.1021/j5504333h

[14] Bhat MK. Cellulases and related enzymes in biotechnology. Biotechnol Adv 2000; 18(5): 355-83. https://doi.org/10.1016/S0734-9750(00)00041-0

[15] Pandey A, Selvakumar P, Soccol CR, Nigam P. Solid state fermentation for the production of industrial enzymes. Curr Sci 1999; 10: 149-62.

[16] Shrestha P, Rasmussen M, Khanal SK, Pometto lii AL, van Leeuwen J. Solid-substrate fermentation of corn fiber by Phanerochaete chrysosporium and subsequent fermentation of hydrolysate into ethanol. J Agric Food Chem 2008; 56(11): 3918-24. https://doi.org/10.1021/jf0728404

[17] Shrestha P, Khanal SK, Pometto III AL, van Leeuwen J. Enzyme production by wood-rot and soft-rot fungi cultivated on corn fiber followed by simultaneous saccharification and fermentation. J Agric Food Chem 2009; 57(10): 4156-61. https://doi.org/10.1021/if900345n

[18] Singhania RR, Sukumaran RK, Patel AK, Larroche C Pandey A. Advancement and comparative profiles in the production technologies using solid-state and submerged fermentation for microbial cellulases. Enzyme and Microb Technol 2010; 46(7): 541-9. https://doi.org/10.1016/j.enzmictec.2010.03.010

[19] Ramachandran P, Kim TS, Dhiman SS, Li J, Park JH, Choi JH, Kim JY, Kim D, Lee JK. Saccharification of sunflower stalks using lignocellulases from a fungal consortium comprising Pholiota adiposa and Armillaria gemina. Bioprocess Biosyst Eng 2015; 38(9): 1645-53. https://doi.org/10.1007/s00449-015-1406-7

[20] Sánchez SR, Sánchez IG, Arévalo-Villena M, Pérez AB. Production and immobilization of enzymes by solid-state fermentation of agroindustrial waste. Bioprocess Biosyst Eng 2015; 38(3): 587-93

https://doi.org/10.1007/s00449-014-1298-y 
[21] Kim S, Kim CH. Production of cellulase enzymes during the solid-state fermentation of empty palm fruit bunch fiber. Bioprocess Biosyst Eng 2012; 35(1-2): 61-7. https://doi.org/10.1007/s00449-011-0595-y

[22] Wilson D. Endophyte: the evolution of a term, and clarification of its use and definition. Oikos 1995; 1: 274-6. https://doi.org/10.2307/3545919

[23] Schulz B, Boyle C. The endophytic continuum. Mycol Res 2005; 109(6): 661-86. https://doi.org/10.1017/S095375620500273X

[24] Sunitha VH, Devi DN, Srinivas C. Extracellular enzymatic activity of endophytic fungal strains isolated from medicinal plants. World J Agric Sci 2013; 9(1): 01-9.

[25] Gond SK, Verma VC, Kumar A, Kumar V, Kharwar RN. Study of endophytic fungal community from different parts of Aegle marmelos Correae (Rutaceae) from Varanasi (India). World J Microbiol Biotechnol 2007; 23(10): 1371-5. https://doi.org/10.1007/s11274-007-9375-x

[26] Weber RW, Stenger E, Meffert A, Matthias HA. Brefeldin A production by Phoma medicaginis in dead pre-colonized plant tissue: a strategy for habitat conquest? Mycol Res 2004; 108(6): 662-71. https://doi.org/10.1017/S0953756204000243

[27] Sharma R, Kumar VB. In Silico Interaction Studies on Inhibitory Action of endophytic fungal Diketopiperazine and its related compounds on Heat-Shock Protein 90 (Hsp90). Asian J Biomed Pharm Sci 2014; 4(28): 25.

[28] Barry DJ, Chan C, Williams GA. Morphological quantification of filamentous fungal development using membrane immobilization and automatic image analysis. J Ind Microbiol Biotechnol 2009; 36(6): 787. https://doi.org/10.1007/s10295-009-0552-9

[29] Brijwani K, Oberoi HS, Vadlani PV. Production of a cellulolytic enzyme system in mixed-culture solid-state fermentation of soybean hulls supplemented with wheat bran. Process Biochem 2010; 45(1): 120-8. https://doi.org/10.1016/j.procbio.2009.08.015

[30] Mosier N, Wyman C, Dale B, Elander R, Lee YY, Holtzapple $M$, Ladisch $M$. Features of promising technologies for pretreatment of lignocellulosic biomass. Bioresour Technol 2005; 96(6): 673-86. https://doi.org/10.1016/j.biortech.2004.06.025
[31] Ishida TA, Nara K, Hogetsu T. Host effects on ectomycorrhizal fungal communities: insight from eight host species in mixed conifer-broadleaf forests. New Phytol 2007; 174(2): 430-40.

https://doi.org/10.1111/j.1469-8137.2007.02016.x

[32] Zhu ZX, Zhuang WY. Trichoderma (Hypocrea) species with green ascospores from China. Persoonia: Molecular Phylogeny and Evolution of Fungi 2015; 34: 113. https://doi.org/10.3767/003158515X686732

[33] Ghose TK. Measurement of cellulase activities. Pure Appl Chem 1987; 59(2): 257-68. https://doi.org/10.1351/pac198759020257

[34] Daisy B, Strobel G, Ezra D, Castillo U, Baird G, Hess W. Muscodor vitigenus anam. sp. nov., an endophyte from Paullinia paullinioides. Mycotaxon 2002; 84: 39-50.

[35] Verma V, Gond S, Kumar A, Kharwar R, Strobel G. The endophytic mycoflora of bark, leaf, and stem tissues of Azadirachta indica A. Juss (neem) from Varanasi (India). Microbial Ecology 2007; 54: 119-125. https://doi.org/10.1007/s00248-006-9179-9

[36] Naik S, Shashikala J, Krishnamurthy Y. Diversity of fungal endophytes in shrubby medicinal plants of Malnad region, Western Ghats, Southern India. Fungal Ecology 2008; 1: 8993. https://doi.org/10.1016/j.funeco.2008.05.001

[37] Schulz B, Boyle C, Draeger S, Römmert AK, Krohn K. Endophytic fungi: a source of novel biologically active secondary metabolites. Mycological Research 2002; 106: 996-1004. https://doi.org/10.1017/S0953756202006342

[38] Sánchez Márquez S, Bills GF, Herrero N, Zabalgogeazcoa I. Non-systemic fungal endophytes of grasses. Fungal Ecology 2011; 5: 289-297. https://doi.org/10.1016/j.funeco.2010.12.001

[39] Gašparovič L, Koreňová Z, Jelemenský L'. Kinetic study of wood chips decomposition by TGA. Chem Pap 2010; 64(2): 174-81.

https://doi.org/10.2478/s11696-009-0109-4 